Acta Agroph., 2019, 26(1), 5-13

doi: $10.31545 /$ aagr/105098

\title{
EFFECT OF SELECTED MICROBIOLOGICAL PRODUCTS ON SOYBEAN SEED GERMINATION CAPACITY
}

\author{
Katarzyna Rymuza®, Elżbieta Radzka®®, Joanna Cała, Pawet Cała, Antoni Bombik \\ Faculty of Natural Sciences, Siedlce University of Natural Sciences and Humanities \\ ul. Prusa 14, 08-110 Siedlce, Poland \\ e-mail: katarzyna.rymuza@uph.edu.pl
}

\begin{abstract}
Germination of three soybean cultivars: Abelina, SG Anser and Merlin was examined in a laboratory study as affected by products containing effective microorganisms: EM5, EM Farma and EM Mulit Grower. Germination in an aqueous environment was the control treatment. Analysis of germination capacity after 5 and 10 days from the beginning of the experiment (as indicated by International Seed Testing Association) was based on two-way analysis of variance. A logistic function was used to analyse the average number of germinating seeds over time (for each cultivar $\times$ product). Based on this function, the rate of germination and the time (day) when the greatest number of seeds germinated were determined. Regardless of the applied product, cv. Abelina had the best germination performance at the first and second date of counting as its germination capacity was 55 and $86 \%$, respectively. An application of EM Farma contributed to a significant increase in seed germination capacity at both the dates compared with the control and the remaining products. No significant differences in the number of germinated seeds counted after 5 and 10 days following EM application were found for cv. Merlin only. The highest number of germinated seeds at the logistic curve inflection point was observed for all the cultivars treated with EM Farma, their germination rate ranging from over 7 to $19 \%$ per $24 \mathrm{hrs}$.
\end{abstract}

Keyw ords: effective microorganisms, soybean cultivars, logistic function, germination rate

\section{INTRODUCTION}

Soybean (Glicine Max (L.) Merrill), is a legume of substantial economic importance grown for consumption and feed production purposes (Michałek 2002, Jarecki and Bobrecka-Jamro 2015, Wilk 2017). The nutritive value of soybean seed is due to a high amount of unsaturated fatty acids, vitamins B and minerals (nitrogen, magnesium, iron, calcium and phosphorus) (Nowak 2011, Wilk 2017). Similarly to other leguminous plants, soybean is a valuable forecrop. Due to symbiosis with 
nitrogen-fixing bacteria, the plant enriches the soil in nitrogen from the air. A well-developed root system is capable of taking up poorly available nutrients which are transferred from sub-soil to the ploughed layer of the soil.

In Poland, soybean production is not very popular due to substantial import of soybean meal for animal feed production purposes (Jerzak et al. 2012, GUS 2018). Also, there are difficulties associated with soybean cultivation mainly due to the crop's substantial thermal requirements and negative response to day length. Good germination and emergence of soybean plants require air and soil temperatures of $10-15$ and $8-10^{\circ} \mathrm{C}$, respectively. Seeds planted too early into cold soil do not germinate but rapidly moulder and decay (Kajdan-Zysnarska 2013). As a result, it is very important to support the process of soybean growth and development by an application of e.g. effective microorganisms which enhance plant germination, flowering, fruit production and maturation. (Higa 2003, Janas 2011). According to Kocoń and Gałązka (2015), microbiological products may also be used to treat seeds.

The objective of the work was to examine the germination capacity of three soybean cultivars following the application of products containing effective microorganisms.

It was hypothesized that the microorganisms positively influenced the germination of soybeans.

\section{MATERIALS AND METHODS}

In order to examine the effect of microbiological products on soybean seed germination, a two-factor random experiment (with three replicates) was set up in a laboratory. The following two factors were investigated:

- factor A - soybean cultivars (Abelina, SG Anser and Merlin),

- factor B - microbiological products (EM 5, EM Farma, EM Multi Grower and water as control) diluted as recommended by the producer.

EM Farma is a product that improves the quality and health of all biological systems. The beneficial microorganisms that it contains support each other and, working together, displace pathogenic microflora, thus changing the direction of the microbiological process to a regenerative or revitalizing one in the place of its application.

EM 5 is a biological pest repellent used to improve plant resistance and limit mould development. A blend of natural ingredients with Effective Microorganisms (EM) strengthens plant resistance to pathogen attacks.

EM Multi Grower - A vaccine for stimulating root growth and boosting plant resistance via seed treatment and spraying at the beginning of the growing season.

Seeds were disinfected in $\mathrm{C}_{2} \mathrm{H}_{5} \mathrm{OH}$ for 24 hours and in $3 \% \mathrm{HClO}_{4}$ solution for 8 hours. Next, the seeds were placed on Petri dishes (50 seeds per dish), on absorbent pads saturated with water or the preparations to $60 \%$ of water holding 
capacity. The temperature of the experiment was constant and remained at $20^{\circ} \mathrm{C}$. Observations of the number of the germinated seeds were made for 16 days, and the recorded values were used to prepare a mathematical description of germination process of seeds representing the analysed cultivars as affected by the applied product.

Two-way ANOVA with the following linear model was used to compare germination capacity:

$$
y_{i j l}=m+a_{i}+b_{j}+a b_{i j}+e_{i j l}
$$

where:

$\mathrm{y}_{\mathrm{ij} 1}$ - value of the examined characteristic (percentage of germinated seeds),

$\mathrm{m}$ - population mean,

$a_{i}$ - effect of the $i-$ th level of factor A (cultivars),

$b_{j}$ - effect of the $j$-th level of factor B (EM product),

$a b_{i j}$ - interaction effect,

$\mathrm{e}_{\mathrm{ijl}}$ - random error.

$\mathrm{i}$ - number of factor A levels $\mathrm{i}=1,2, \ldots \mathrm{a} ; \mathrm{a}=3$;

$\mathrm{j}$ - number of factor $B$ levels $\mathrm{j}=1,2, \ldots \mathrm{b} ; \mathrm{b}=4$;

1 - number of replicates $1=1,2, \ldots n ; n=3$

Analysis of variance was performed for the number of seeds which germinated after the $5^{\text {th }}$ and $10^{\text {th }}$ day of the experiment as indicated by ISTA (2003) Regulations. The results were subjected to Bliss transformation (Trętowski 1991).

In order to mathematically describe the number of germinated seed over time, the following logistic function was used:

$$
y(t)=\frac{A}{1+B \cdot e^{-K \cdot t}}
$$

where:

$y(t)$ - the percentage of germinated seeds on the t-th day,

A - value of the horizontal asymptome (estimated value),

$\mathrm{B}, \mathrm{K}$ - coefficients of germination (estimated values).

On the basis of the obtained models seed germination rate as well as function inflection points were calculated following the equations (Gregorczyk 1991):

germination rate: $\quad \frac{d y}{d t}=\frac{k}{a} \cdot y(t) \cdot[a-y(t)]$

coordinates of function inflection points: $t_{i}=\frac{\ln b}{k}, y\left(t_{i}\right)=0.5 \cdot a$

All the calculations were performed using the program Statistica 12. 


\section{RESULTS}

Soybean seed germination capacity at the first date depended on the cultivar and applied microbiological product. Also, interaction between cultivars and microbiological products was significant. The germination rate of cv. Abelina was $43 \%$ and it was significantly higher compared with cv. Anser (25.7\%) and Merlin (29.3\%) whose germination was at a similar level.

The application of EM 5 and EM Multi Grower contributed to a decline in germination capacity compared with the control, the differences being insignificant. Regardless of the cultivar, soybean seeds treated with EM Farma germinated by almost $6 \%$ better compared with the control or the remaining products. The numbers of seeds germinating due to the effect of EM 5 and EM Multi Grower were the same. The fact that the interaction of cultivar $\mathrm{x}$ microbiological product was significant indicates that the cultivars responded differently to the applied products. Seed germination capacity of cv. SG Anser and Merlin was the same regardless of the type of microbiological product applied. $\mathrm{Cv}$. Abelina germinated significantly better due to the application of EM Farma (Tab. 1).

The number of germinated seeds after 10 days was significantly affected by cultivar and microbiological product. Also, a significant cultivars $\mathrm{x}$ products interaction was observed. At the second date, cv. Abelin had a significantly better germination capacity which was $89.5 \%$. Moreover, the germination capacity of $\mathrm{cv}$. SG Anser and Merlin was the same. The highest number of germinated seeds at the second date was found following the application of EM $5(88.9 \%)$, it being the lowest for EM Farma (86.2\%). The differences between the effect of these products were statistically significant. $\mathrm{Cv}$. Abelina germinated the best when exposed to EM 5. The number of germinated seeds was over $92 \%$, the value being significantly higher compared to EM Multi Grower (87.3\%). The seed germination capacity of cv. SG Anser significantly increased following the application of EM 5, compared with the control (by over 5\%). The germination capacity of $\mathrm{cv}$. Merlin after 10 days ranged from 84 to $87.8 \%$ but the differences were statistically insignificant (Tab. 2).

Table 1. Percentage of germinated soybean seeds as affected by the cultivar and product after 5 days from the beginning of the experiment

\begin{tabular}{lccccc}
\hline \multirow{2}{*}{ Cultivar } & \multicolumn{5}{c}{ Product } \\
\cline { 2 - 6 } & Water & EM Farma & EM 5 & EM Multi Grower & Mean \\
\hline Abelina & $44.0 \mathrm{~b}$ & $55.0 \mathrm{a}$ & $40.3 \mathrm{~b}$ & $34.0 \mathrm{~b}$ & $43.3 \mathrm{a}$ \\
SG Anser & $27.0 \mathrm{a}$ & $27.7 \mathrm{a}$ & $24.8 \mathrm{a}$ & $23.2 \mathrm{a}$ & $25.7 \mathrm{~b}$ \\
Merlin & $27.7 \mathrm{a}$ & $33.4 \mathrm{a}$ & $26.5 \mathrm{a}$ & $29.6 \mathrm{a}$ & $29.3 \mathrm{~b}$ \\
Mean & $32.9 \mathrm{~b}$ & $38.7 \mathrm{a}$ & $30.5 \mathrm{~b}$ & $29.0 \mathrm{~b}$ & \\
\hline
\end{tabular}

* - means followed by different letters (in row) differ significantly at $\mathrm{p} \leq 0.05$ 
Table 2. Percentage of germinated soybean seeds as affected by the cultivar and product after 10 days from the beginning of the experiment

\begin{tabular}{llcccc}
\hline \multirow{2}{*}{ Cultivar } & \multicolumn{5}{c}{ Product } \\
\cline { 2 - 6 } & Water & EM Farma & EM 5 & EM Multi Grower & Mean \\
\hline Abelina & $89.7 \mathrm{ab}$ & $88.7 \mathrm{ab}$ & $92.3 \mathrm{a}$ & $87.3 \mathrm{~b}$ & $89.5 \mathrm{a}$ \\
SG Anser & $83.7 \mathrm{~b}$ & $86.0 \mathrm{ab}$ & $88.8 \mathrm{a}$ & $87.6 \mathrm{ab}$ & $86.5 \mathrm{~b}$ \\
Merlin & $87.8 \mathrm{a}$ & $84.0 \mathrm{a}$ & $85.7 \mathrm{a}$ & $87.0 \mathrm{a}$ & $86.0 \mathrm{~b}$ \\
Mean & $87.0 \mathrm{ab}$ & $86.2 \mathrm{~b}$ & $88.9 \mathrm{a}$ & $87.3 \mathrm{ab}$ & \\
\hline
\end{tabular}

$*$ - means followed by different letters (in row) differ significantly at $\mathrm{p} \leq 0.05$

Based on the model of logistic function it was found that water contributed to the most rapid germination of $\mathrm{cv}$. SG Anser as the function inflection point occurred the earliest (after almost 5 days). The number of germinated seeds was then higher than $44 \%$ and the average rate of this germination was over $24 \%$ per 24 hours. For cv. Merlin, the highest number of germinated seeds was after 6 days (almost 50\%), the average increase per 24 hours being $15 \%$. Similar parameters were obtained for the germination model of cv. Abelina (Tab. 3).

Table 3. Parameters describing soybean seed germination in the control treatment, obtained based on the logistic model

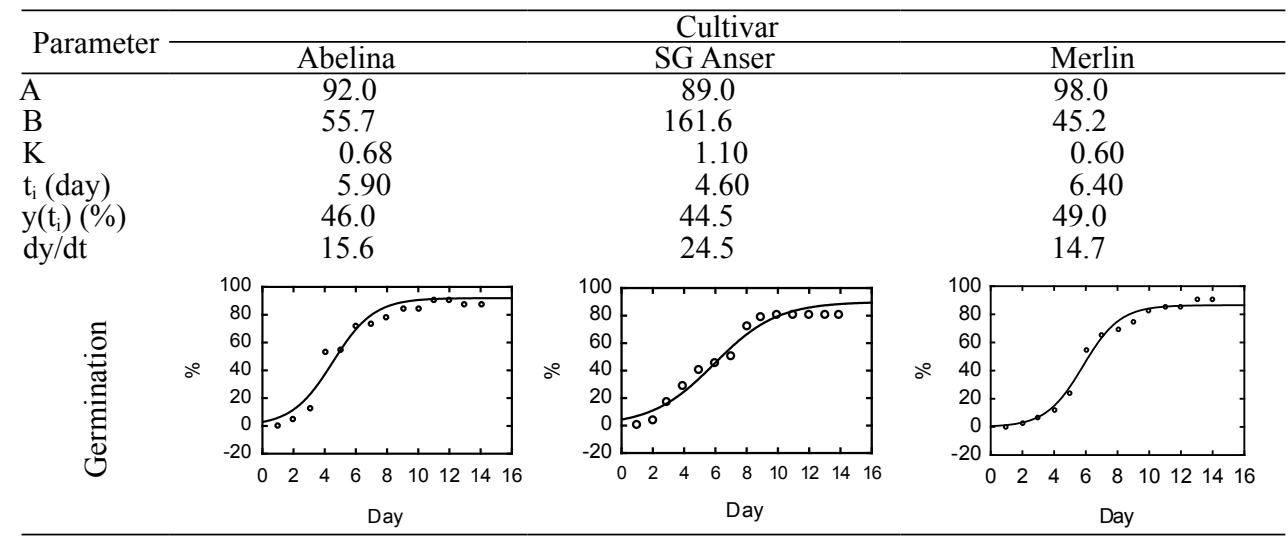

A, B, K- estimated parameters of the function

EM Farma contributed to the most rapid germination of cv. Abelina. The inflection of its function occurred on the $4.6^{\text {th }}$ day of the experiment and the average seed germination rate was $16.5 \%$ per 24 hours (Tab. 4). For cv. Merlin, the application of EM Farma reduced the time in which the highest number of seeds germinated, from 6.4 to 5.1 days, compared with the control, but also a decline in the average germination rate was observed, from 14.7 to $12.2 \%$ (Tabs 3 and 4). Seed germination of cv. Merlin treated with EM 5 and EM Multi Grower followed a similar pattern. The highest number of germinated seeds was noted after 5 days of the experiment and the average germination rate fluctuated around $12 \%$ per 24 hours (Tabs 5 and 6). 
Table 4. Parameters describing soybean seed germination as affected by the application of EM Farma, obtained based on the logistic model

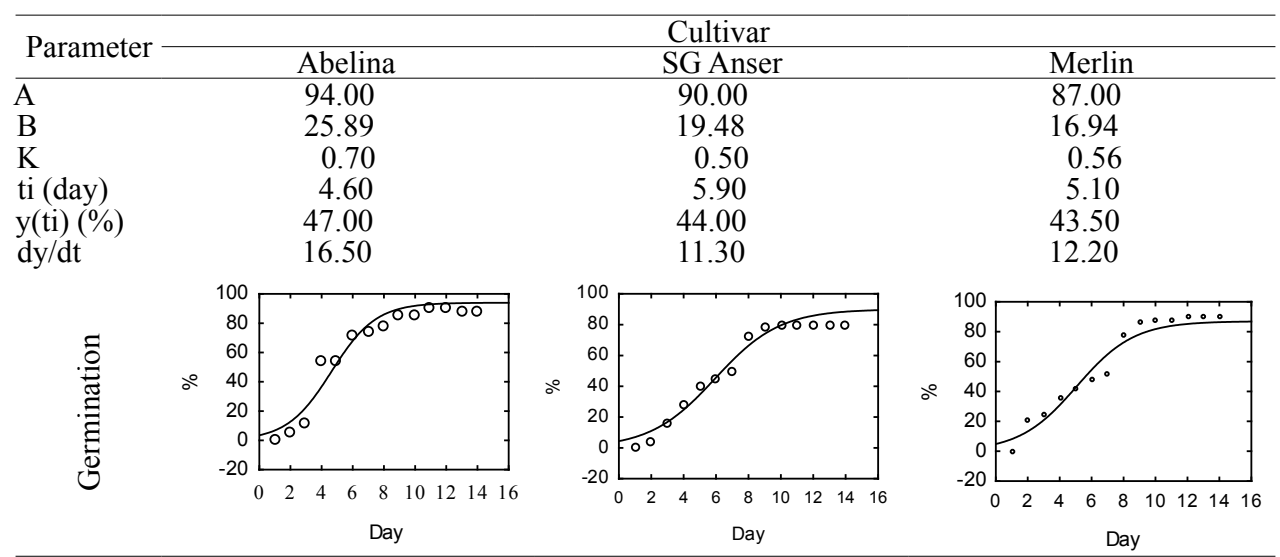

A, B, K- estimated parameters of the function

Table 5. Parameters describing soybean seed germination as affectedby the application of EM 5, obtained based on the logistic model

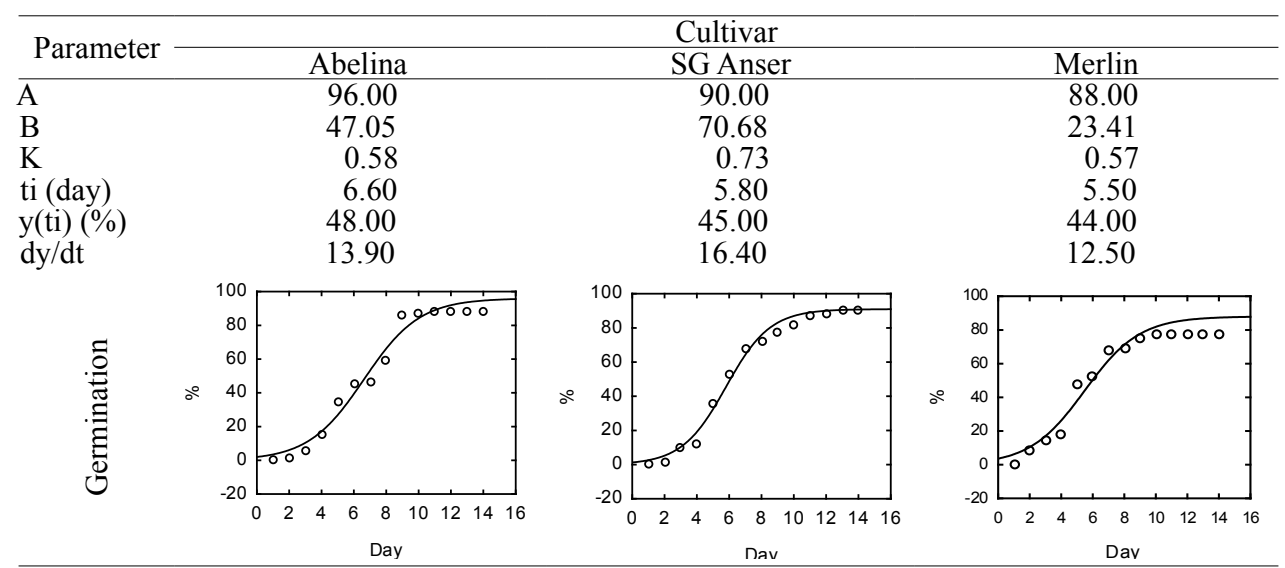

A, B, K- estimated parameters of the function

\section{DISCUSSION}

Soybean seed production in Poland remains at a low level although recently a renewed interest in the cultivation of this crop has been observed. Thus, research on new soybean cultivars has gained new importance (Michałek and Borowski 2006). According to PIORiN (Main Inspectorate of Plant Health and Seed Inspection), production of soybean for seed was on the increase in 2010-2015. Also, there has been 
an increase in the number of cultivars available for purchase in Poland (there are currently 36 registered varieties of soybeans). Of particular interest are Polish cultivars which are not genetically modified. Soybean yield quantity and quality are affected by habitat conditions, but predominantly by the applied agrotechnology (Jarecki and Borecka-Jamro 2015). Cultivation of various crop plants increasingly includes the application of substances which offer a wide range of benefits including comprehensive protection of plants and stimulation of their resistance to diseases and adverse agrometeorological conditions (Janas 2009). Such substances include effective microorganisms whose effect is associated with multi-directional influence of various antagonistic groups of microorganisms (Valarini et al. 2003, Kaczmarek et al. 2008). The substances are also used to treat seeds.

Table 6. Parameters describing soybean seed germination as affected by the application of EM Multi Grower obtained based on the logistic model

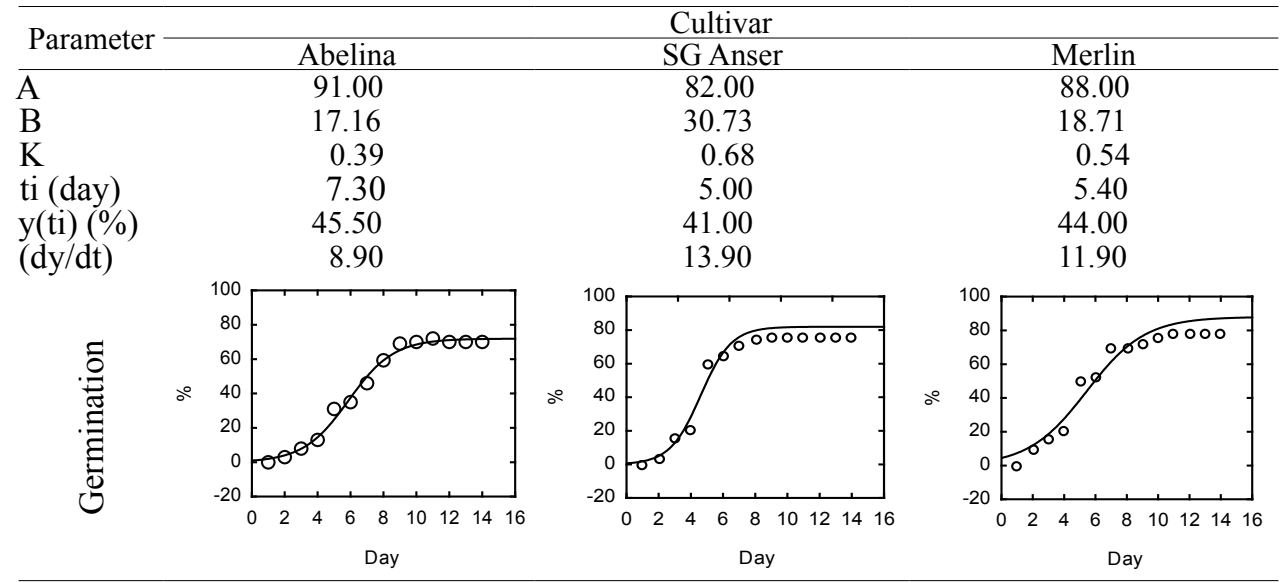

A, B, K- estimated parameters of the function

Apart from the work by Michałek and Borowski (2002), there has virtually been no research on soybean seed germination capacity so far. The above-mentioned authors examined the effect of a decline in water potential on germination capacity of seven Polish soybean cultivars. They demonstrated that a decline in water potential of a solution significantly reduced the number of germinated seeds, proper germination being possible when water potential was 0.0 to $-0.4 \mathrm{MPa}$. Under controlled conditions (water potential 0.0 ), the seed germination capability they recorded ranged from 92 to $100 \%$. These values are higher than the findings of the research reported here.

The application of products containing effective microorganisms contributed to changes in seed germination capacity of cv. Abelina at the first date, and in SG Anser at the second date, compared with the control. An increase in the number 
of germinated seeds was observed following the application of EM Farma (at the first date) and EM5 (at the second date). Research conducted by Małuszyńska et al. (2012) demonstrated no significant effect of EM Farma on germination of organic seed. However, those authors recorded an increase in the germination capacity of serradella and lacy phacelia seeds treated with the bioproduct Ema Plus and ISD. Faltyn and Miszkieło (2008) demonstrated that wheat seeds germinate better following the application of the standard vs. increased rate of the bioproduct.

\section{CONCLUSIONS}

1. Soybean seed germination capacity at the first and second date was affected by cultivar and applied EM product. Cv. Abelina was the best performer, and germination of cv. SG Anser and Merlin was at a similar level.

2. Seeds germinated better after applying EM Farma (on first date). At the second date, the highest number of germinated seeds was obtained for EM 5.

3. At the first date, germination capacity of cv. SG Anser and Merlin was the same for all the examined EM products. Cv. Abelina germinated significantly better following the application of EM Farma. At the second date, cv. Abelinai SG and Anser performed the best when treated with EM 5.

4. Based on the logistic function it was found that the highest number of germinated seeds was recorded between days 5 and 7, the average germination rate ranging from 9 to $16 \%$ per 24 hours (depending on cultivar and EM product).

\section{REFERENCES}

Faltyn U., Mizkieło T., 2008. The influence of formulations containing effective microorganisms on germination capacity of organic seeds (in Polish) Zesz. Nauk. Uniw. Przyrod. Wroc., 568, 31-37.

Gregorczyk A., 1991. The logistic function - its application to the description and prognosis of plant growth. Acta Societatis Botanicorum Poloniae, 60(1-2), 67-76, https://doi.org/10.5586/ asbp. 1991.004

GUS, 2018. Stat.gov.pl

Higa T., 2003. Revolution in the protection of our planet (in Polish). SGGW Development Foundation, SGGW, Warszawa, 1-152.

ISTA, 2003. Handbook of vigour test methods.

Janas R., 2009. Possibilities of utilisation of effective microorganisms in organic crop plant production systems (in Polish). Probl. Inż. Rol., 3, 111-119.

Janas R., 2011. The influence of biological compounds with different mechanisms of action on the metabolism of plants and seed quality of garden rocket. (in Polish). Biul IHAR 262, 197-206.

Jarecki W., Bobrecka-Jamro D., 2015. Influence of foliar feeding on yield and chemical composition of soyabean seeds (Glycine Max (L.) Merrill) (in Polish). Fragm. Agron., 32(4), 22-31.

Jerzak M., Czerwińska-Kayzer D., Florek J., Śmiglak-Krajewska M., 2012. Determinants for the production of legumes as an alternative source of protein in the new area of agricultural policy in Poland (in Polish). Rocz. Nauk. Rol., Ser. G, 99(1), 113-120. 
Kaczmarek Z., Jakubas M., Grzelak M., Mrugalska L., 2008. Impact of the addition of various doses of Effective Microorganisms to arable-humus horizons of mineral soils on their physical and water properties. J. Res. and Appl. in Agric. Eng., 53(3), 118-121.

Kajdan-Zysnarska I., 2013. Soybean cultivation in Polish climatic conditions (in Polish). wyd. Centrum Doradztwa Rolniczego, oddział w Poznaniu.

Kocoń A., Gałązka A., 2015. The effect of products containing effective microorganisms on physio-chemical properties of soil and plant yield (in Polish). Studia i Raporty IUNG-BIP 45(19), 113-125.

Małuszyńska E., Szydłowska A., Martyniak D., Dziamba S., Dziamba J., 2012. The influence of formulations containing effective microorganisms on germination capacity of organic seeds (in Polish). Biul. IHAR 263, 33-42.

Michałek S., Borowski E., 2002. Seed germination and seedling growth of the Polish soybean (Glycine max (L.) cultivars in drought conditions (in Polish). Biul. IHAR 223/224, 195-201.

Nowak A., 2011. Soybean (Glycine Max L. MERR.)- important dietary and medical ingredient. Kosmos. Problemy nauk biologicznych 60(1-2), 179-187.

STATISTICA - StatSoft, Inc. (2014). STATISTICA (data analysis software system), version 12. www. statsoft.com.STATISTICA.

Trętowski J., 1991. Methodology of agricultural experiments (in Polish). WSRP Siedlce.

Valarini P.J., Alvarez M.C.D., Gasco J.M., Guerrero F., Tokeshi H., 2003. Assessment of soil properties by organic matter and EM - microorganisms incorporation. R. Bras. Ci. Solo., 27, 519-525, https://doi.org/10.1590/S0100-06832003000300013

Wilk M., 2017. Soya As A Source Of Valuable Nutrients (in Polish). Żywność, Nauka. Tech. Jakość, 24(2), 111, 16-25. 